\title{
Mapping of reforestation progress in Chilean National Park Torres del Paine
}

\author{
Ítalo Márquez ${ }^{\mathrm{a}}$, Guido Staub ${ }^{\mathrm{a}^{*}}$ \\ ${ }^{a}$ University of Concepción, Departmento for Geodetic Sciences and Geomátics, J. A. Coloma 0201, 4451032 Los Ángeles, Chile. \\ Ítalo Marquez, italomarquez@udec.cl, Guido Staub, gstaub@udec.cl \\ * Corresponding author
}

\begin{abstract}
:
The Torres del Paine National Park is one of the most important of the world due to its particular biotic characteristics, climate and geomorphologic conditions (Mattar et. al, 2012), which makes unique with invaluable attractions for tourists and scientists. Furthermore it is one of the main sources of income generated by tourism in Chile. It is located in the southernmost Chilean region namely Magallanes and Chilean Antarctica and comprises a total of 242242 hectares.

Since 1980 several forest fires inside the national park have caused great losses to flora and fauna. Despite several initiatives carried out by the national forest cooperation (CONAF) to reduce the number of forest fires, it was not possible to install sustainable management plans. As a consequence, it is still of huge concern that most of the forest fires are caused by tourists and visitors to the national park. Such as those in 2005 and 2011, that caused damage to a total surface of about 33000 hectares. As a consequence CONAF started to implement an updated reforestation strategy in 2012. The plan prepared by the committee was designed for a period of five years (2012-2016) proposing passive and active restoration measures based on the different ecosystems involved in the national park as it is necessary to reconstruct the original ecosystems and to conserve the biodiversity of the park. For this purpose, it was considered a study carried out by Pisano (1974) and the cartography that defined the park before a 1985 forest fire.

The aim of the present study is to quantify and to analyse reforestation campaigns carried out since 2012 in the Torres del Paine National Park. Therefore, we processed Landsat 7 and Landsat 8 satellite imagery acquired between 2011 and 2017. Our methodology is based on the calculation and comparison of the Normalized Burn Ratio.

Our approach indicates that almost 19000 hectares were affected by forest fires that took place in 2005 and 2012. Of the total area affected, 17761 hectares presented some degree of severity, of which $28 \%$ presented a high degree of severity. Up to 2017 , a total of 13067 hectares have been recovered, representing a $70 \%$ of the total area affected by the forest fires.

After 2012, annual soil recovery can be estimated by $11 \%$, or 1100 hectares. Nevertheless, this does not mean that leafy and tall trees can be found in areas affected by forest fires. It just indicates that soil recuperation has taken part and that vegetation seems to grow. As CONAF principally planted Lenga (Nothofagus Pumilio) a slow growing tree species, almost 15 years have to pass before notable effects can be perceived.
\end{abstract}

Keywords: Forest fire, Remote Sensing, NBR

\section{Introduction}

The Torres del Paine National Park (PNTP - Parque Nacional Torres del Paine) has been affected by a series of forest fires in the last 30 years. They have caused great damage, not only to the soil, but also to the flora and fauna of the area. In recent years, the PNTP has had to face a series of forest fires produced by reckless human activity and that have consumed a total of close to 45,000 hectares of native vegetation (CONAF, 2007). As a result, not only the landscape in general has been affected, but also tourism, one of the main sources of income in the region of Magallanes and Chilean Antarctica, has suffered.

In the most recent event, which began on 27 December 2011, the National Forestry Corporation (CONAF Corporación Nacional Forestal) reported the appearance of a fire spot inside the PNTP, which unleashed a new forest fire. This was the largest fire that has affected the area and, according to Abumohor (2012), consumed a total of 17,600 hectares.

In response to this catastrophe and as a measure of recuperation CONAF planned a couple of reforestation campaigns, restore affected soils and recuperate part of the heritage that was lost. Finally, in 2012, these reforestation processes began and, according to Alejandra Silva, regional director of CONAF, they developed irregularly due to the strong winds, less favorable land conditions and predatory behavior of the fauna, which is present in the PNTP. At the end of the first period, which took place between 2012 and 2014, 99203 Nothofagus pumilio plants were planted in the Paine River, Lake Pehoé and Pudeto sectors. The most recent campaign of the reforestation process (2014 - 2015) added a total of approximately 200000 Nothofagus pumilio. Subsequent reports from CONAF indicated that by the end of 2016 it was estimated to produce an additional plantation of 
80,000 new Nothofagus pumilio in the PNTP. Furthermore, it was proposed to design and execute a Monitoring Program regarding the progress of soil recovery and reforestation in those areas affected by the 2012 forest fire.

The aim of this research was to characterize the state of the soils after the forest fire and to estimate the surface that has presented some degree of recovery in the vegetation by terms of reforestation and/or natural recovery.

\section{Study site}

According to Mattar et al. (2012), Chilean Patagonia has biotic, climatic and geomorphologic characteristics that make it one of the main reserves of wildlife on the planet, with invaluable tourist and scientific attractions. Located in the largest region in the country, Patagonia has a large area of protected wild areas, among which are the Bernardo O'Higgins National Park, the Cabo de Hornos National Park and Torres del Paine National Park. Torres del Paine National Park is located in the Province of Última Esperanza in the region of Magallanes and Chilean Antarctica, between latitude $50^{\circ}$ $45^{\prime} \mathrm{S}$ and $51^{\circ} 20^{\prime} \mathrm{S}$ and between longitude $72^{\circ} 31^{\prime} \mathrm{W}$ and $73^{\circ} 22^{\prime} \mathrm{E}$ (Figure 1).

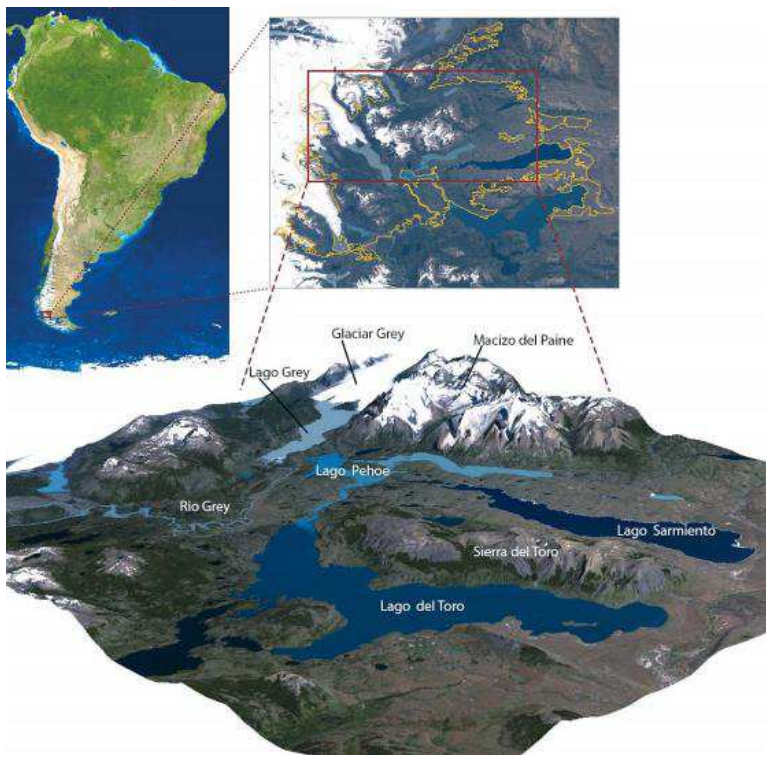

Figure 1: Location of Torres del Paine National Park

The most populated centers nearby are Cerro Castillo, Puerto Natales and Punta Arenas, at 50, 112 and 310 kilometres, respectively. It was funded on May 13, 1959, by Supreme Decree No. 383 of the Ministry of Agriculture with an approximate area of 4332 hectares under the name of Gray National Tourism Park. In 1961 it was given the name Torres del Paine National Tourism Park by expanding the boundaries and including the mountain group Cordillera Paine, covering a total area of 24532 hectares. In 1970 new limits are defined and it is given the name by which it is known today. The current limits of the park were established in the mid-seventies and according to CONAF it covers an area of 242242 hectares.

Famous for the granite vertical formations (Torres), the structures of sedimentary rocks (Cuernos), the huge variety of the purest ecosystems of wildlife on the planet, and a great diversity of fauna in a state of protection, the United Nations Educational, Scientific and Cultutral Organization (UNESCO) in 1978 granted the PNTP the status of a Biosphere Reserve, as part of the Man and the Biosphere Programme (MAB). Among the mammals that inhabit the PNTP are Pumas (Puma concolor), Huemules (Hippocamelus bisulcus), Guanacos (Lama guanicoe), Chilla (Lycalopex griseus), Culpeo (Lycalopex culpaeus), the Chingue (Conepatus chinga) and wildcats (Leopardus geoffroyi). Among the main birds present in the park, is the Condor (Vultur gryphus) and also some other species such as Caiquenes (Chloephaga picta), Black-necked swans (Cygnus melanocoryphus) or bronze-winged duck (Speculanas specularis). The flora of the area, according to the studies carried out by Pisano (1974), is grouped into four large groups: Preandean scrub, Magellanic Forest, Patagonian Steppe and Andean Desert. In general, it is characterized by the ability to adapt in terms of water storage and resistance to strong winds that hit the pampas during most of the year.

\subsection{Forest Fires}

During the last 30 years, 44 forest fires were registered in the PNTP. According to CONAF (2007) Some 44,000 hectares were affected. Most of these events were originated in camping sites and could easily be controlled, due to the presence of fire-fighters in the nearby vicinity. Nevertheless, other events originated in places not authorized for camping were not that easy to control due to lack of accessibility and trained personnel. The last three fires of great magnitude (1985, 2005, 2011), have been caused by carelessness of tourists who visited the park. On February 10, 1985, a Japanese tourist caused the first major catastrophe in the PNTP, leaving a cigar unlit and throwing it on the trails of the park. CONAF was able to extinguish the fire on February 25, 1985. As a result of this incident, 12983 hectares of native vegetation were burned (CONAF, 2009). The second forest fire was in the Laguna Azul sector on February 17, 2005, twenty years after the first catastrophe. This time, an overheated stove by a Czech tourist originated the fire. After almost 4 weeks, it was extinct for complete. This time a total of 15470 hectares were burned, of which 11,685 hectares belonged to the PNTP and 3,785 hectares were privately owned, according to statistical reports (ONEMI, 2009).

The most recent disaster, which occurred inside the park, had its origin in the Olguín sector (south of Refugio Gray), on December 27, 2011, in the vicinity of Gray Lake, on a mountainous path, of difficult vehicular access. Due to the constant winds, the fire spread for a period of three weeks, and finally extinguished one month later (February 24 2011). This catastrophe was not only the longest one, but also the one of greatest 
magnitude witnessed in the PNTP ever, with a total area of 17603 hectares burnt.

\subsection{Reforestation}

A particular restoration plan contemplates a period of five years (2012-2016) proposing passive and active restoration measures, considering the different ecosystems involved and that it is necessary to reconstruct the original ecosystems to conserve the biodiversity of the park itself. For this purpose, a study carried out by Pisano (1974) and the cartography that defined the park before the 1985 fire were considered. Based on this information, together with an updated ground cover archive, by means of aerial photography (after the 2012 fire), geology studies (soils, slope, etc.), plans for the degradation of the soil associated with the loss of vegetation cover due to fire and zoning of the sector, it was possible to identify actual restoration potential. The plantation of woody species over extensive areas is a very inefficient and highly expensive restoration technique (Parrota \& Engel 2001, Benayas et al., 2008), so planting of small blocks of trees or shrubs was proposed, which mimics the natural regeneration process known as nucleation, which frequently occurs in open areas with strong environmental limitations. In this process, the first group of vegetation manages to establish itself, but in patches, in forms of vegetation islands that coalesce in time. Figure 2 shows the different stages of the mentioned planting process.

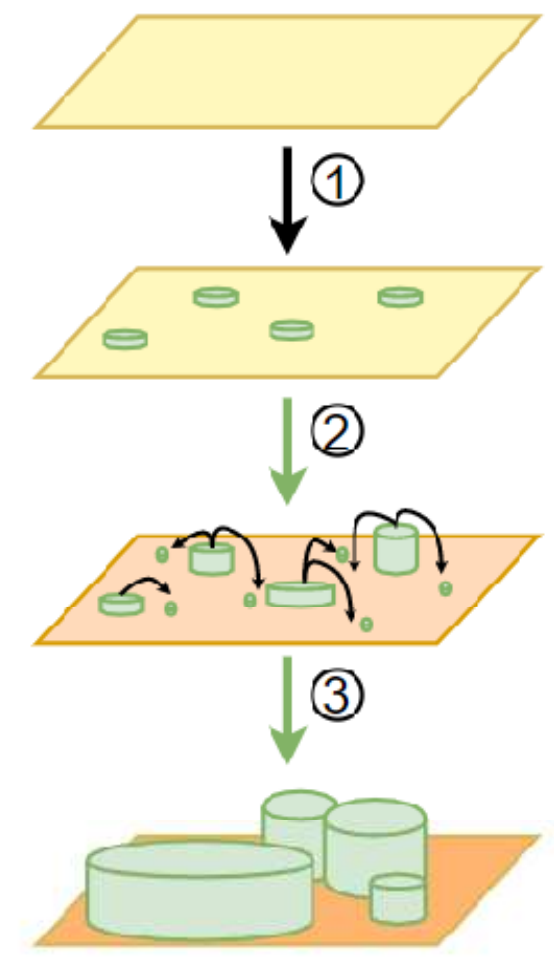

Figure 2 Proposed planting process for reforestation purposes
The restoration process, as far as the planting of the seeds is concerned, does not require highly specialized personnel. It is for this reason, that year after year, voluntary participation campaigns were organized. One of the most recent campaigns (2015), named 20 thousand Nothofagus pumilio for Paine, was considered one of the best socio-environmental projects in Latin America, according to the Green Latin Awards. It was funded with more than 20,000 native trees in areas that were affected by the fire in 2012 . The proposal brought together 32 million pesos, which is equivalent to 16,015 Nothofagus pumilio plants and which involved the participation of six thousand volunteers from the Magallanes and Chilean Antarctica region.

\section{Methodology}

\subsection{Satellite Images}

Satellite images acquired by Landsat 7 and Landsat 8 between 2011 and 2017 were used in the present study. The images from path 230 and row 096 show the entire PNTP. In addition, low cloud cover had to be guaranteed and was therefore set to $10 \%$ as maxima.

\subsection{Burnt Areas Estimate}

In order to be able to compare the burnt areas in 2012 and the evolution of them over the years, it was necessary to delimit the affected. This was done by manually digitizing the burned area, based on to the Landsat 7 ETM+ image (visualized in false color) corresponding to February 24, 2012.

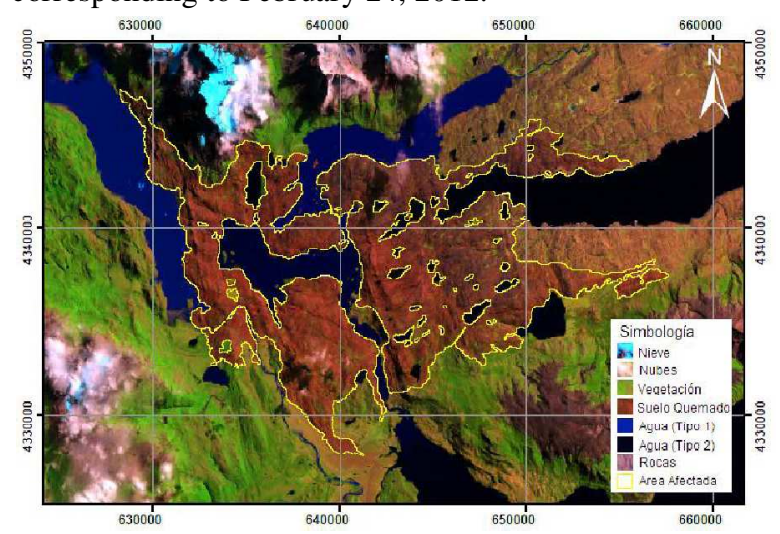

Figure 3 Burnt areas (2012)

\subsection{Characterization of Soil Conditions}

Applying the formula for the Normalized Burn Ratio $(\mathrm{NBR}=(\mathrm{NIR}-\mathrm{SWIR}) /(\mathrm{NIR}+\mathrm{SWIR}))$ on a pre-fire satellite image (2005) and on each of the images corresponding to the period of time under study a $\triangle$ NBR was obtained

For each $\triangle \mathrm{NBR}$ a particular soil condition was identified as sown in table 1 .

Table 1 Soil state indicators

\begin{tabular}{|l|l|}
\hline \multicolumn{1}{|c|}{$\boldsymbol{\Delta N B R}$} & \multicolumn{1}{c|}{ Soil condition } \\
\hline$<-0.25$ & High growth (post fire) \\
\hline$-0.25--0.1$ & Low growth (post fire) \\
\hline
\end{tabular}




\begin{tabular}{|l|l|}
\hline$-0.1-0.1$ & Not burnt \\
\hline $0.2-0.27$ & Burnt (low severity) \\
\hline $0.27-0.44$ & Burnt (medium severity) \\
\hline $0.44-0.66$ & $\begin{array}{l}\text { Burnt (medium high } \\
\text { severity) }\end{array}$ \\
\hline$>0.66$ & Burnt (high severity) \\
\hline
\end{tabular}

\subsection{Progress Comparison}

The intervention and insertion of Nothofagus pumilio plants was carried out in areas prioritized by CONAF, so not all vegetation growth presented in the park is caused by these actions. Considering this, natural (Sierra del Toro and Sector Sarmiento sectors) and human driven (Pudeto sector and Gray sector) soil improvements were compared.

\section{Results}

A comparison between the images before and after the fire, corresponding to January 3, 2005 and February 24, 2012 respectively was carried out. By manual digitization, a total burnt area of 18595 hectares was estimated, obtaining a difference of 900 hectares with respect to the official values delivered by CONAF (17603 hectares)

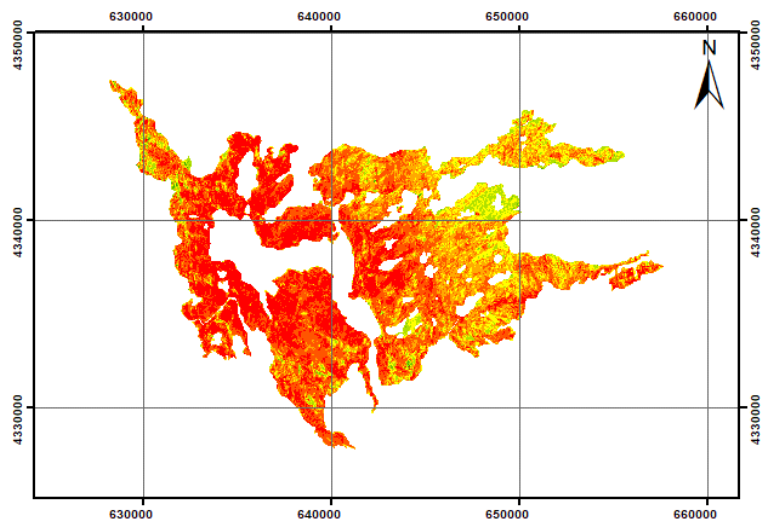

Figure 4 Burnt areas after 2012 forest fire (scale severity ranges from high: red to low: green)

Of the total area affected, 17761 hectares presented some degree of severity, of which $28 \%$ presented a high degree of severity. On the other hand, 833 hectares presented a degree of recovery after the fire or were not burned. One year after the fire, based on the results obtained, the area that showed some degree of recovery was 12745 hectares, of which 2956 hectares showed a low growth after the fire. For the year 2014, an area of 9095 hectares with some degree of severity was identified. 9499 hectares showed some degree of recovery. Although in 2013 the numbers do not show a positive trend towards recovery, they do so later on (table 2).

Table 2 Area affected post forest fire

\begin{tabular}{|c|c|c|}
\hline Year & $\begin{array}{l}\text { Not-Burnt (and/or } \\
\text { recovered) }\end{array}$ & $\begin{array}{l}\text { Burnt with some degree } \\
\text { of severity }\end{array}$ \\
\hline 2012 & $4.48 \%$ & $95.52 \%$ \\
\hline
\end{tabular}

\begin{tabular}{|l|l|l|}
\hline 2013 & $68.54 \%$ & $31.46 \%$ \\
\hline 2014 & $51.09 \%$ & $48.91 \%$ \\
\hline 2015 & $56.82 \%$ & $43.18 \%$ \\
\hline 2016 & $62.13 \%$ & $37.87 \%$ \\
\hline 2017 & $70.27 \%$ & $29.73 \%$ \\
\hline
\end{tabular}

For the year 2015, it was obtained that the surface that presented a degree of recovery was 331 hectares, of which $92 \%$ are in the category with low post-fire growth. Considering the soils classified as unburned, the surface was estimated to 10565 hectares, thus leaving a total of 8,029 hectares that still show some degree of severity. In 2016, the area estimated and classified, with low and high regeneration, was 596 hectares, $140 \%$ more compared to previous year, leaving an area of 11,553 hectares that have presented some degree of improvement after the forest fire took place. Finally, it was obtained that the surface that presented regeneration or is classified as unburned, for the year 2017 was 13067 hectares, of which $10 \%$ have a high degree of regeneration.

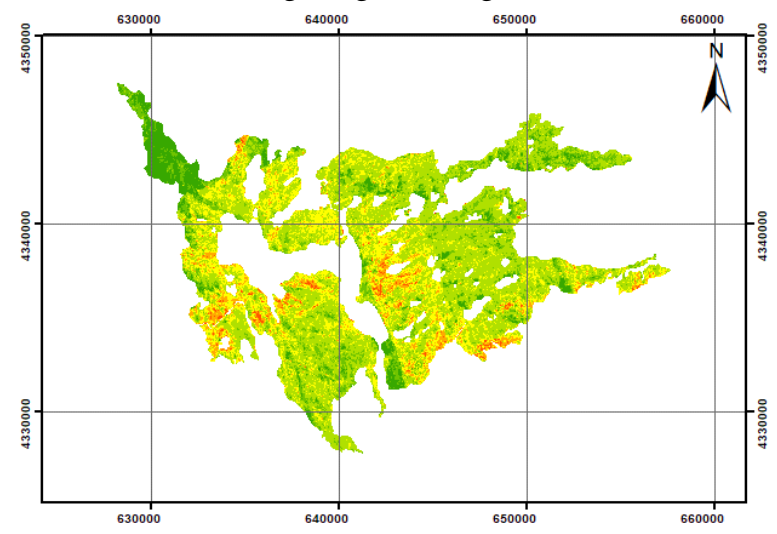

Figure $5 \triangle N B R$ in 2017 with respect to 2016 (recuperation scale ranges from high: dark green to low: orange)

So, $70 \%$ of the total area initially affected by the fire has regenerated. Annually, the reforestation campaigns managed to recover $11 \%$ of the surface that had some degree of severity with respect to the previous year. With respect to the actions carried out by the authorities, the soils intervened in Sector Pudeto showed an increase with low and high growth after the fire, of $25 \%$ and $12 \%$ of the total area of this sector, respectively. On the other hand, the Sierra del Toro sector showed a slight increase with low growth, maintaining the slow trend in the other categories. The Sarmiento sector, which initially was not much affected, presented a better recovery, in terms of low recovery, presenting a $24 \%$ of the total area in this category, keeping relatively constant $(75 \%-85 \%)$ the surfaces that did not show negative effects after the fire. Based on the results of the classification, it can be seen that the improvement of soils presents a sense of progress that goes from the shores of Lake Sarmiento inland, until reaching the east bank of Lake Pehoé. This advance can be justified, in certain form, with the low slope variations that exist in these sectors. Not so in the mountainous sectors around Laguna Negra and Laguna Margarita. 
Although, the reforestation actions of CONAF are centred in the sectors of greater tourist transit (Pehoé, Sarmiento, Gray, among others), the recovery in other sectors, occurs in a natural way.

\section{Conclusions}

Since 1985, in which the PNTP was affected by the first major fire, efforts are being made to recover what was somehow lost in such catastrophes. Unfortunately, almost twenty years later, a new catastrophe prevented a continuous soil recovery, forcing the responsible national and local institutions to restart these recovery campaigns. Annual reforestation campaigns inside the PNTP are carried out since 2012, in the sectors of Lago Pehoé, Laguna Calafate and Laguna Honda. The reforestation work, carried out by CONAF, is essential so that the process of ecological regeneration can take place. Planting of seeds or plants in affected areas is only one step of this complex process. Regeneration process requires much more time and work, which does not necessarily depend on the personnel of CONAF or others, but rather on the capacity of the soil to recover, the survival capacity of the planted species and the environment in which it grows. After 2012, an annual advance in soil recovery of $11 \%$ can be observed with respect to the previous year, which is equivalent to a total of 1100 hectares. This does not mean that in these sectors are leafy forests and tall trees, but rather soils that present improvements with respect to the date of the fire. The Nothofagus pumilio has a very slow growth, so it requires at least 15 years, before notable effects can be perceived. Therefore, at an initial stage, improvements in terms of soil composition and presence of organic material can be observed. The reforestation actions in sites prioritized by CONAF, presented better results than those obtained in the isolated sites, or that were not involved in the reforestation campaigns (Sierra del Toro and Sarmiento). Although Pudeto presented a considerable increase in vegetation coverage with respect to Sierra del Toro, this did not happen in the same way as it did in the Sarmiento sector. Therefore it is possible to conclude that natural recovery process, will present different advances according to the sector in which the vegetation is located. Sierra del Toro is a mountainous sector of elevations between the 500 and 700 meters, with slopes higher than those of the Sarmiento sector, the latter being a sector of small hills and plains, located on the shores of Lake Sarmiento. In this sense, the vegetation which grows in sectors of greater exposure to wind and steeper slopes, it must present a greater resistance and survivability than that existing in plains near water bodies.

\section{References}

Abumohor, J. (2012). Incendio forestal Parque Nacional Torres del Paine. Recuperado de:

http://repositoriodigitalonemi.cl/web/bitstream/handle/2 012/1613/ConsolidadoIncendioForestalTdelPaine2011_ 2012.pdf
Benayas, J., Bullock, K., Newton A. (2008). Creating woodland islets to reconcile ecological restoration, conservation and agricultural land use. Frontiers in Ecology and the Enviroment, 6, 329-336.

Corporación Nacional Forestal (CONAF). (2007). Plan de manejo Parque Nacional Torres del Paine. Recuperado de: http://www.conaf.cl/wpcontent/files_mf/PNTorresdelPaine.PDF. 54

Corporación Nacional Forestal (CONAF). (2009). Los grandes incendios forestales en Chile 1985-2009. Recuperado de http://www.conaf.cl/wpcontent/files_mf/1397681623GrandesIncendios2009.pdf

Corporación Nacional Forestal (CONAF). (2012). Programa Integral de Mejoramiento de la Gestión del Parque Nacional Torres del Paine. Recuperado de: http://www.parquetorresdelpaine.cl/upload/files/planmejoramiento-pntop-conaf.pdf.

Mattar, C., Satamaría-Artigas, A., Durán-Alarcon, C. (2012). Estimación del área quemada en el Parque Nacional Torres del Paine utilizando datos de teledetección. Revista de Teledetección, 38, 36-50.

Oficina Nacional de Emergencia del Ministerio del Interior (ONEMI). (2009). Incendio Forestal Torres del Paine año 2005. Recuperado de http://repositoriodigitalonemi.cl/web/bitstream/handle/2 012/406/Incendio\%20Forestal\%20Torres\%20del\%20Pa ine $\% 202005 \% 20-\% 20$ Magallanes.pdf.

Parrota, J., Engel, V. (2001). An evaluation of direct seeding for reforestation of degraded lands in central São Paulo state, Brazil. Forest, Ecology and Management, 152, 169-181, doi: 10.1016/S03781127(00)00600-9.

Pisano E. (1974). Estudio ecológico de la región continental sur del área andino patagónica II. Contribución a la fitogeografía de la zona del Parque Nacional "Torres del Paine". Anales del Instituto de la Patagonia 5: 59-104. 